Supplement of Atmos. Chem. Phys., 21, 15221-15237, 2021

https://doi.org/10.5194/acp-21-15221-2021-supplement

(C) Author(s) 2021. CC BY 4.0 License.

(c) (i)

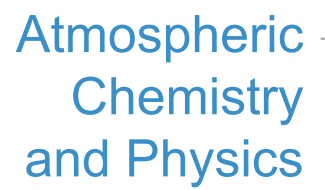

Supplement of

\title{
Formation and evolution of secondary organic aerosols derived from urban-lifestyle sources: vehicle exhaust and cooking emissions
}

Zirui Zhang et al.

Correspondence to: Min Hu (minhu@pku.edu.cn)

The copyright of individual parts of the supplement might differ from the article licence. 
34 Section S1. Details about vehicle and cooking laboratory experiments

35 Section S2. Go: PAM conditions

36 Table S1. Comparison of results between blank and experimental groups (Dilution air and boiled water are two kinds of blank 37 groups. The others are experimental groups).

38 Table S2. Test engine information.

39 Table S3. Catalyst system information.

40 Table S4. The comparison of SOA/POA between SMPS and AMS-PMF results. "SOA/POA (SMPS)" means the mass ratio 41 gained from SMPS-1 and SMPS-2. "SOA/POA (AMS-PMF)" means the mass ratio gained from PMF analysis of aged OA measured by HR-Tof-AMS.

43 Table S5. VOCs measured by GC-MS at the inlet of Go: PAM.

44 Table S6. $\mathrm{K}_{\mathrm{OH}}$ of major species in Go: PAM.

45 Table S7. Comparison of primary (no O3, UV OFF), $\mathrm{O}_{3}$ oxidation (certain $\mathrm{O}_{3}$, $\mathrm{UV} \mathrm{OFF}$ ) , and $\mathrm{OH}$ oxidation (certain $\mathrm{O}_{3}$, $\mathrm{UV}$ 46 ON) results during the cooking experiment.

Figure S1. Profile of Go: PAM.

Figure S2. Comparison of measured and estimated $\mathrm{OH}$ exposures during off-line $\mathrm{OH}$ exposure calibration of the vehicle experiment.

Figure S3. Comparison of measured and estimated $\mathrm{OH}$ exposures during off-line $\mathrm{OH}$ exposure calibration of the cooking 51 experiment.

Figure S4. Previous performance tests for Go: PAM.

Figures S5-S8. Mass spectra of PMF-resolved POA and SOA factors for the cooking experiment.

Figures S9-S12. Diagnostic plots of the PMF analysis for the cooking experiment. 
Section S1: Details about vehicle and cooking laboratory experiments.

The vehicle experiment was conducted from July to October in 2019, at the Department of Automotive Engineering, Tsinghua University. For all experiments, the gasoline direct injection (GDI) engine ran in a single room, its exhaust was drawn into the pipeline and then entered the Go: PAM at a 30 fold dilution where aerosols and gases reacted at a stable temperature and relative humidity. The GDI engine was equipped with a three-way catalyst system, and its parameters are shown in Table S2S3. The cooking experiment was conducted from November 2019 to January 2020, at Langfang Branch, Institute of Process Engineering, Chinese Academy of Sciences. The cooking time and oil temperature were different due to the inherent features of the ingredients. For all experiments, the closed kitchen was full of fumes where the vision was blurred and the air was choky after a long time of the cooking process. Subsequently, the cooking fumes were drawn into pipeline from a kitchen to a lab and then entered the Go: PAM at an 8 fold dilution where aerosols and gases reacted at a stable temperature and relative humidity. From the sampling port at the source (cooking and vehicle) to the inlet of HR-ToF-AMS, the 3/8 inch (inner diameter was $6 \mathrm{~mm}$ ) stainless steel tubes were totally 7 meters long and the corresponding residence time was $4.9 \mathrm{~s}$. There were 5 meters long from the sampling port to the Go: PAM, the flow rate was $5.5 \mathrm{~L} / \mathrm{min}$ (HR-Tof-AMS and other instruments jointly determined the flow rate), and the penetrating fraction was more than $90 \%$ for those particles whose diameter was larger than $10 \mathrm{~nm}$ (equivalent pipe length method) (Wiedensohler et al., 2012). There were 2 meters long from the Go: PAM to the HRToF-AMS, the flow rate was $1 \mathrm{~L} / \mathrm{min}$ (HR-ToF-AMS and its drainage system determined the flow rate), and the penetrating fraction was more than $88 \%$ for those particles whose diameter was larger than $10 \mathrm{~nm}$ (equivalent pipe length method) (Wiedensohler et al., 2012).

The dilution air was ambient air (clean period), which was firstly filtered by a particle filter system (including a dryer, a filter, and an ultrafilter, SMC Inc.) in order to remove the particles and water. Then the dilution air was filtered by an activated carbon adsorption device, in order to remove the VOCs. The vehicle exhaust from the tailpipe was first diluted by a gradient heated dilution system ( 6 fold) and then diluted by an unheated dilution system ( 5 fold). The temperature of sample flow was near indoor temperature after secondary dilution systems. The cooking fumes were collected through the kitchen ventilator. The boiled water can be a background sample influenced by indoor air, iron wok, and ventilator. As the results of blank groups in Table S1 show, the dilution air and background interference just made a minor influence on the SOA concentration. Besides, a temperature controller and heat insulation cotton were wrapped around the sampling pipelines to prevent freshly warm gas from condensing on the pipe wall. Silicon tubes were used to dry the emissions before they entered measuring instruments. The particle densities were measured through the determination of the DMA-CPMA-CPC system (DMADifferential Mobility Analyzer; CPMA- Centrifugal Particle Mass Analyzer; CPC- Condensation Particle Counter) in our study. Prior to each experiment, all pipelines and the Go: PAM chamber were continuously flushed with purified dry air until the concentrations of gases and particles were minimal. Furthermore, blank experiments were separately designed in the presence of boiling water emissions or dilution air under the same condition. The results of blank groups can be found in Table S1. When the $\mathrm{OH}$ exposure was zero, OA concentrations derived from dilution air were so low that they couldn't be 
quantified correctly. On the whole, the OA concentrations of blank groups were far below those of experimental groups. The field study was deployed at the Institute of Atmospheric Physics (IAP), Chinese Academy of Sciences $\left(39^{\circ} 58^{\prime} \mathrm{N} ; 1^{\prime} 16^{\circ} 22^{\prime} \mathrm{E}\right)$ in autumn and winter (Autumn: Oct. 1st, 2018 - Nov. 15th, 2018; Winter: Jan. 5th, 2019 - Jan. 31st, 2019) (Li et al., 2020a). The sample site is located in the south of Beitucheng West Road and west of Beijing Chengde expressway in Beijing, which is a typical urban site affected by local emissions ( $\mathrm{Li}$ et al., 2020b).

\section{Section S2: Go: PAM conditions}

As Figure S1 shows, the flow reactor of Go: PAM is made of quartz glass (1) (Raesh GmbH RQ 200), which is $100 \mathrm{~cm}$ long and $9.6 \mathrm{~cm}$ in diameter. About $84 \mathrm{~cm}$ of the flow reactor may be illuminated by either one or two Philips TUV $30 \mathrm{~W}$ fluorescent tubes (2), each radiating about $10 \mathrm{~W}$ at $254 \mathrm{~nm}$. It is enclosed in a compartment of aluminum mirrors, in order to reduce the inhomogeneity of the photon field inside the reactor. The fluorescent tubes and quartz tubes are surrounded by a parabolic trough mirror (3), $90 \mathrm{deg}$. flat mirror (4) and 45-90 deg. flat mirrors (5). The shell of Go: PAM is composed of a sheath metal cover (6) and square tubing support structure (7) (Watne et al., 2018). As for the vehicle and cooking experiment, the photon flux at $254 \mathrm{~nm}$ was $4.5 \times 10^{14}$ and $2.2 \times 10^{15}$ photons $\cdot \mathrm{cm}^{-2} \cdot \mathrm{s}^{-1}$, respectively.

Table $\mathrm{S} 7$ shows the comparison of primary (no $\mathrm{O}_{3}$, UV OFF), $\mathrm{O}_{3}$ oxidation (certain $\mathrm{O}_{3}$, UV OFF) and $\mathrm{OH}$ oxidation (certain $\mathrm{O}_{3}$, UV ON) results during the cooking experiment. There is no significant increase in OA mass when we just add $\mathrm{O}_{3}$ with UV off, comparing to those of $\mathrm{OH}$ oxidation groups (input $\mathrm{O} 3$ with $\mathrm{UV}$ on). Overall, our Go: PAM could reasonably simulate the $\mathrm{OH}$ oxidation process of cooking $\mathrm{OA}$ in ambient. The detailed information of gaseous compounds and their $\mathrm{K}_{\mathrm{OH}}$ can be found in Table S5-S6. The $\mathrm{K}_{\mathrm{OH}}$ for each specie was taken from the updated Carter research results (http://www.engr.ucr.edu/ carter/reactdat.htm,last access: 24 February 2021).

The mixing and wall loss tests have already conducted in previous work using the same Go: PAM according to Li et al.(Li et al., 2019) and Watne et al (Watne et al., 2018). In Figure $\mathrm{S} 3(\mathrm{a}), \mathrm{SO}_{2}$ was continually injected into the "4 Humidified oxidant flow" and "5 Sample flow", and was measured through "3 Processed sample flow" (Watne et al., 2018). As shown in Figure S3(b), there was nearly no difference when using different inlets, which demonstrated a great mixing of the sample and oxidant flow in the Go: PAM (Watne et al., 2018). Figure S3(c) modeled the wall loss of LVOC (low-volatility VOC) following the method of Palm et al (Watne et al., 2018;Palm et al., 2016). The results indicated that most LVOC tended to react with OH or condensate on particles rather than exit or cause loss to the wall ( $\mathrm{Li}$ et al., 2019). Figure S3(d) tested the particle wall loss using nebulized ammonium sulfate particles. Results showed that the particle losses with size above $22.1 \mathrm{~nm}$ were nearly smaller than $10 \%$ which would only make a negligible effect in Go: PAM (Watne et al., 2018), while in this study, we still corrected the wall loss of particle in each size bin measured by two synchronous SMPS (two SMPS run before and after Go: PAM respectively). 
Table S1. Comparison of results between blank and experimental groups (Dilution air and boiled water are two kinds of blank 133 groups. The others are experimental groups).

\begin{tabular}{|c|c|c|c|c|}
\hline Experiment & $\begin{array}{c}\text { OH Exposure } \\
\left(\times 10^{10} \text { molecules } \cdot \mathrm{cm}^{-3} \cdot \mathrm{s}\right)\end{array}$ & OA Concentration $(\mu \mathrm{g} / \mathrm{m} 3)$ & $\begin{array}{l}\text { Standard } \\
\text { Deviation }\end{array}$ & $\begin{array}{l}\text { Relative Standard } \\
\text { Deviation }\end{array}$ \\
\hline \multirow{2}{*}{ Dilution Air (cooking) } & 0 & - & - & - \\
\hline & 9.6 & 0.37 & 0.04 & $12 \%$ \\
\hline \multirow{2}{*}{ Boiled Water } & 0 & 0.04 & 0.02 & $44 \%$ \\
\hline & 9.6 & 0.36 & 0.12 & $32 \%$ \\
\hline \multirow{2}{*}{ Deep-fried Chicken } & 0 & 12.30 & 0.49 & $4 \%$ \\
\hline & 9.6 & 28.29 & 2.55 & $9 \%$ \\
\hline \multirow{2}{*}{ Shallow-fried Tofu } & 0 & 13.56 & 0.68 & $5 \%$ \\
\hline & 9.6 & 21.70 & 1.08 & $5 \%$ \\
\hline \multirow{2}{*}{ Stir-fried Cabbage } & 0 & 10.75 & 0.65 & $6 \%$ \\
\hline & 9.6 & 18.38 & 1.65 & $9 \%$ \\
\hline \multirow{2}{*}{ Kung Pao Chicken } & 0 & 6.47 & 0.52 & $8 \%$ \\
\hline & 9.6 & 11.39 & 1.25 & $11 \%$ \\
\hline \multirow{2}{*}{ Dilution Air (vehicle) } & 0 & - & - & - \\
\hline & 7.8 & 0.52 & 0.07 & $13 \%$ \\
\hline \multirow{2}{*}{ GDI $20 \mathrm{~km} / \mathrm{h}$} & 0 & 0.40 & 0.01 & $3 \%$ \\
\hline & 7.8 & 19.68 & 1.48 & $8 \%$ \\
\hline \multirow{2}{*}{ GDI $40 \mathrm{~km} / \mathrm{h}$} & 0 & 0.41 & 0.01 & $3 \%$ \\
\hline & 7.8 & 15.24 & 0.62 & $4 \%$ \\
\hline \multirow{2}{*}{ GDI $60 \mathrm{~km} / \mathrm{h}$} & 0 & 0.42 & 0.02 & $5 \%$ \\
\hline & 7.8 & 23.23 & 4.00 & $17 \%$ \\
\hline
\end{tabular}

Table S2. Test engine information.

\begin{tabular}{cc}
\hline Specification & GDI \\
\hline Displaced Volume & $998 \mathrm{cc}$ \\
Stoke & $78.6 \mathrm{~mm}$ \\
Bore & $73.4 \mathrm{~mm}$ \\
Compression ratio & 9.6 \\
Max power/ engine speed & $100 \mathrm{~kW} / 6000 \mathrm{rpm}$ \\
Max torque / engine speed & $205 \mathrm{~N} \cdot \mathrm{m} / 2000-3000 \mathrm{rpm}$ \\
\hline
\end{tabular}

Table S3. Catalyst system information.

\begin{tabular}{cc}
\hline Specification & Three-way catalyst system \\
\hline Volume & $1.19 \mathrm{~L}$ \\
Material & Cordierite \\
Diameter & $132.1 \mathrm{~mm}$ \\
Length & $87.1 \mathrm{~mm}$ \\
Cell & $900 /$ inch $^{2}$ \\
\hline
\end{tabular}

Table S4. The comparison of SOA/POA between SMPS and AMS-PMF results. "SOA/POA (SMPS)" means the mass ratio gained from SMPS-1 and SMPS-2. "SOA/POA (AMS-PMF)" means the mass ratio gained from PMF analysis of aged OA measured by HR-Tof-AMS.

\begin{tabular}{|c|c|c|c|c|c|c|c|c|c|c|}
\hline \multirow{2}{*}{$\begin{array}{l}\text { Photochemical Age } \\
\left(\text { days, }[\mathrm{OH}]=1.5 \times 10^{6}\right. \\
\left.\text { molecules } \cdot \mathrm{cm}^{-3}\right)\end{array}$} & \multicolumn{2}{|c|}{ Deep Fried Chicken } & \multicolumn{2}{|c|}{ Shallow-fried Tofu } & \multicolumn{2}{|c|}{ Stir-fried cabbage } & \multicolumn{2}{|c|}{ Kung Pao Chicken } & \multicolumn{2}{|c|}{ Cooking Average } \\
\hline & $\begin{array}{c}\text { SOA/POA } \\
(\text { AMS-PMF) }\end{array}$ & $\begin{array}{l}\text { SOA/POA } \\
\text { (SMPS) }\end{array}$ & $\begin{array}{c}\mathrm{SOA} / \mathrm{POA} \\
(\mathrm{AMS}-\mathrm{PMF})\end{array}$ & $\begin{array}{l}\mathrm{SOA} / \mathrm{POA} \\
\text { (SMPS) }\end{array}$ & $\begin{array}{c}\text { SOA/POA } \\
(\mathrm{AMS}-\mathrm{PMF})\end{array}$ & $\begin{array}{l}\mathrm{SOA} / \mathrm{POA} \\
\text { (SMPS) }\end{array}$ & $\begin{array}{c}\text { SOA/POA } \\
\text { (AMS-PMF) }\end{array}$ & $\begin{array}{l}\mathrm{SOA} / \mathrm{POA} \\
\text { (SMPS) }\end{array}$ & $\begin{array}{c}\text { SOA/POA } \\
(\text { AMS-PMF) }\end{array}$ & $\begin{array}{c}\mathrm{SOA} / \mathrm{POA} \\
\text { (SMPS) }\end{array}$ \\
\hline 0.3 & 0.63 & 0.46 & 0.34 & 0.34 & 0.50 & 0.41 & 0.53 & 0.51 & 0.50 & 0.43 \\
\hline 0.7 & 1.84 & 1.29 & 1.29 & 0.61 & 0.93 & 0.71 & 0.87 & 0.77 & 1.23 & 0.84 \\
\hline 1.1 & 2.21 & 2.13 & 1.97 & 0.81 & 1.87 & 1.14 & 1.44 & 1.22 & 1.87 & 1.33 \\
\hline 1.7 & 2.30 & 2.41 & 3.32 & 1.27 & 1.95 & 1.57 & 4.57 & 1.92 & 3.03 & 1.79 \\
\hline 2.1 & 3.23 & 3.16 & 4.50 & 1.81 & 2.04 & 2.05 & 6.28 & 2.48 & 4.01 & 2.38 \\
\hline
\end{tabular}


Table S5. VOCs measured by GC-MS at the inlet of Go: PAM.

\begin{tabular}{|c|c|c|c|c|c|c|}
\hline Expriment & TVOCs (ppbV) & Alkane (\%) & Alkene (\%) & Aromatic (\%) & O-VOC (\%) & $\mathrm{X}-\operatorname{VOC}(\%)$ \\
\hline GDI $20 \mathrm{~km} / \mathrm{h}$ & 33 & $60 \%$ & $6 \%$ & $12 \%$ & $13 \%$ & $9 \%$ \\
\hline GDI $40 \mathrm{~km} / \mathrm{h}$ & 35 & $55 \%$ & $7 \%$ & $13 \%$ & $13 \%$ & $12 \%$ \\
\hline GDI $60 \mathrm{~km} / \mathrm{h}$ & 29 & $54 \%$ & $6 \%$ & $12 \%$ & $14 \%$ & $13 \%$ \\
\hline Deep-fried Chicken & 139 & $21 \%$ & $7 \%$ & $6 \%$ & $29 \%$ & $37 \%$ \\
\hline Shallow-fried Tofu & 124 & $57 \%$ & $9 \%$ & $10 \%$ & $18 \%$ & $7 \%$ \\
\hline Stir-fried Cabbage & 127 & $48 \%$ & $8 \%$ & $14 \%$ & $21 \%$ & $10 \%$ \\
\hline Kung Pao Chicken & 189 & $64 \%$ & $8 \%$ & $11 \%$ & $5 \%$ & $13 \%$ \\
\hline
\end{tabular}

Table S6. $\mathrm{K}_{\mathrm{OH}}$ of major species in Go: PAM.

\begin{tabular}{|c|c|}
\hline Species & $\mathrm{K}_{\mathrm{OH}}\left(\mathrm{cm}^{-3} \cdot\right.$ molecules $\left.^{-1} \cdot \mathrm{s}^{-1}\right)$ \\
\hline \multicolumn{2}{|l|}{ Alkanes } \\
\hline Ethane & $2.48 \mathrm{E}-13$ \\
\hline iso-Pentane & $3.59 \mathrm{E}-12$ \\
\hline Propane & $1.09 \mathrm{E}-12$ \\
\hline n-Butane & $2.36 \mathrm{E}-12$ \\
\hline iso-Butane & $2.12 \mathrm{E}-12$ \\
\hline n-Pentane & $3.79 \mathrm{E}-12$ \\
\hline 2,3-Dimethylbutane & $5.77 \mathrm{E}-12$ \\
\hline 3-Methylpentane & $5.19 \mathrm{E}-12$ \\
\hline n-Hexane & $5.19 \mathrm{E}-12$ \\
\hline n-Butane & $2.36 \mathrm{E}-12$ \\
\hline 1,2-Dichloroethane & $2.39 \mathrm{E}-13$ \\
\hline 2,3-Dimethylpentane & $1.50 \mathrm{E}-12$ \\
\hline 3-Methylpentane & $5.19 \mathrm{E}-12$ \\
\hline Methylcyclopentane & $8.60 \mathrm{E}-12$ \\
\hline 2-Methylpentane & $5.19 \mathrm{E}-12$ \\
\hline 2-Methylheptane & $7.00 \mathrm{E}-12$ \\
\hline n-Heptane & $6.76 \mathrm{E}-12$ \\
\hline \multicolumn{2}{|l|}{ Alkenes } \\
\hline Ethylene & $8.52 \mathrm{E}-12$ \\
\hline Isoprene & $1.00 \mathrm{E}-10$ \\
\hline Propene & $2.62 \mathrm{E}-11$ \\
\hline trans-2-Pentene & $6.69 \mathrm{E}-11$ \\
\hline \multicolumn{2}{|l|}{ Aromatics } \\
\hline $\mathrm{m} / \mathrm{p}$-Xylene & $1.87 \mathrm{E}-11$ \\
\hline Toluene & $5.63 \mathrm{E}-12$ \\
\hline 1,2,4-Trimethylbenzene & $3.25 \mathrm{E}-11$ \\
\hline o-Xylene & $1.36 \mathrm{E}-11$ \\
\hline Benzene & $1.22 \mathrm{E}-12$ \\
\hline $\mathrm{m} / \mathrm{p}$-Xylene & $1.87 \mathrm{E}-11$ \\
\hline \multicolumn{2}{|l|}{ O-VOCs } \\
\hline Acetaldehyde & $1.50 \mathrm{E}-11$ \\
\hline Acetone & $1.70 \mathrm{E}-13$ \\
\hline MTBE & $2.93 \mathrm{E}-12$ \\
\hline MethylEthylKetone & $1.22 \mathrm{E}-12$ \\
\hline MethylVinylKetone & $2.00 \mathrm{E}-11$ \\
\hline n-Hexanal & 2.99E-11 \\
\hline Acrolein & $2.00 \mathrm{E}-11$ \\
\hline n-Pentanal & $2.79 \mathrm{E}-11$ \\
\hline \multicolumn{2}{|l|}{ X-VOCs } \\
\hline Tetrachloroethylene & $1.59 \mathrm{E}-13$ \\
\hline MethyleneChloride & $1.48 \mathrm{E}-13$ \\
\hline Freon & $0.00 \mathrm{E}+00$ \\
\hline Chloroform & $1.03 \mathrm{E}-13$ \\
\hline Chloromethane & $4.30 \mathrm{E}-14$ \\
\hline \multicolumn{2}{|l|}{ Inorganic } \\
\hline $\mathrm{SO}_{2}$ & $9.00 \mathrm{E}-13$ \\
\hline $\mathrm{NO}_{\mathrm{x}}$ & $1.00 \mathrm{E}-11$ \\
\hline
\end{tabular}


Table S7. Comparison of primary (no O3, UV OFF), $\mathrm{O}_{3}$ oxidation (certain $\mathrm{O}_{3}$, $\mathrm{UV}$ OFF) and $\mathrm{OH}$ oxidation (certain $\mathrm{O}_{3}$, $\mathrm{UV}$

$148 \mathrm{ON})$ results during the cooking experiment.

\begin{tabular}{|c|c|c|c|c|c|c|}
\hline Experiment & $\begin{array}{l}\text { Input } \mathrm{O}_{3} \text { concentration } \\
(\mathrm{ppbV})\end{array}$ & UV & $\begin{array}{c}\text { OH Exposure }\left(\times 10^{10}\right. \\
\left.\text { molecules } \cdot \mathrm{cm}^{-3} \cdot \mathrm{s}\right)\end{array}$ & $\begin{array}{c}\mathrm{OA} \\
\text { Concentration } \\
(\mu \mathrm{g} / \mathrm{m} 3)\end{array}$ & $\begin{array}{l}\text { Standard } \\
\text { Deviation }\end{array}$ & $\begin{array}{c}\text { Relative } \\
\text { Standard } \\
\text { Deviation }\end{array}$ \\
\hline \multirow{2}{*}{ Dilution Air (cooking) } & - & OFF & 0 & - & - & - \\
\hline & - & ON & 9.6 & 0.37 & 0.04 & $12 \%$ \\
\hline \multirow{2}{*}{ Boiled Water } & - & OFF & 0 & 0.04 & 0.02 & $44 \%$ \\
\hline & - & ON & 9.6 & 0.36 & 0.12 & $32 \%$ \\
\hline \multirow{3}{*}{ Deep-fried Chicken } & - & OFF & 0 & 12.30 & 0.49 & $4 \%$ \\
\hline & 1183 & OFF & - & 14.50 & 0.20 & $1 \%$ \\
\hline & 1183 & ON & 9.6 & 28.29 & 2.55 & $9 \%$ \\
\hline \multirow{3}{*}{ Shallow-fried Tofu } & - & OFF & 0 & 13.56 & 0.68 & $5 \%$ \\
\hline & 1183 & OFF & - & 14.79 & 3.25 & $22 \%$ \\
\hline & 1183 & $\mathrm{ON}$ & 9.6 & 21.70 & 1.08 & $5 \%$ \\
\hline \multirow{3}{*}{ Stir-fried Cabbage } & - & OFF & 0 & 10.75 & 0.65 & $6 \%$ \\
\hline & 1183 & OFF & - & 12.70 & 0.72 & $6 \%$ \\
\hline & 1183 & ON & 9.6 & 18.38 & 1.65 & $9 \%$ \\
\hline \multirow{3}{*}{ Kung Pao Chicken } & - & OFF & 0 & 6.47 & 0.52 & $8 \%$ \\
\hline & 1183 & OFF & - & I & I & I \\
\hline & 1183 & $\mathrm{ON}$ & 9.6 & 11.39 & 1.25 & $11 \%$ \\
\hline
\end{tabular}

6

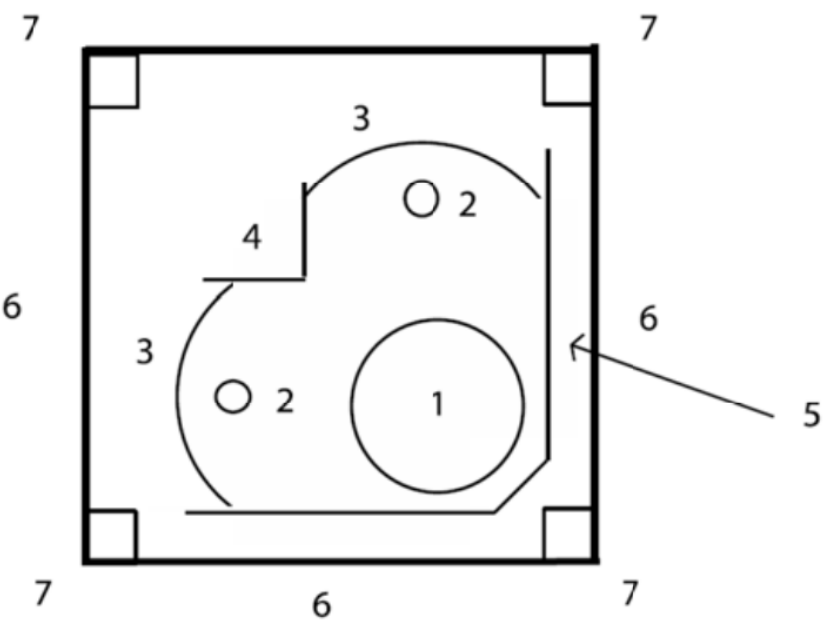

152 Figure S1. Profile of Go: PAM. (1) $9.6 \mathrm{~cm}$ quartz tube (2) fluorescent tube (3) parabolic trough mirror (4)90 deg. flat 153 mirror (5) 45-90 deg. flat mirror (6) sheath metal cover (7) Square tubing support structure (Watne et al., 2018). 


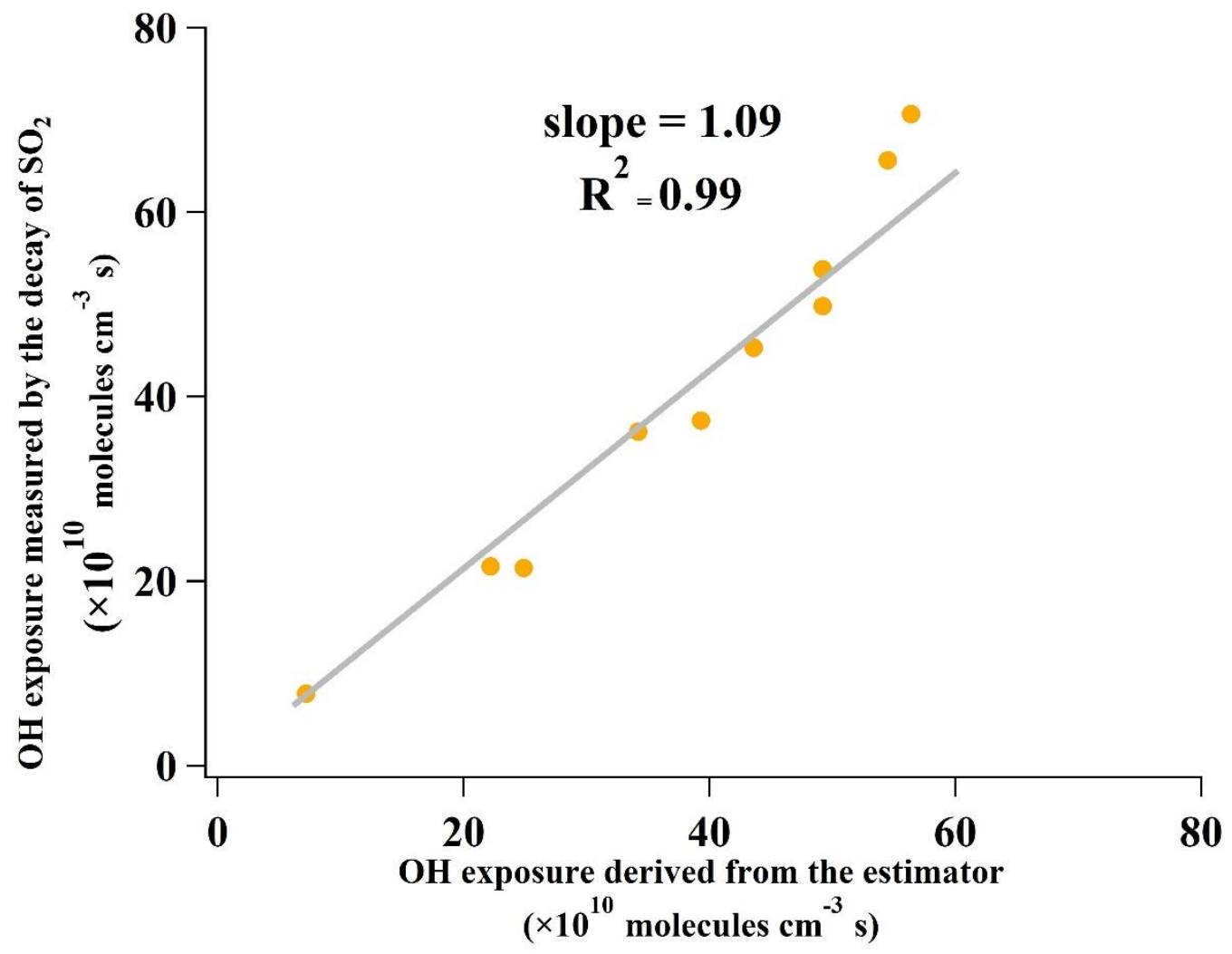

Figure S2. Comparison of measured and estimated $\mathrm{OH}$ exposures during off-line $\mathrm{OH}$ exposure calibration of the vehicle experiment.

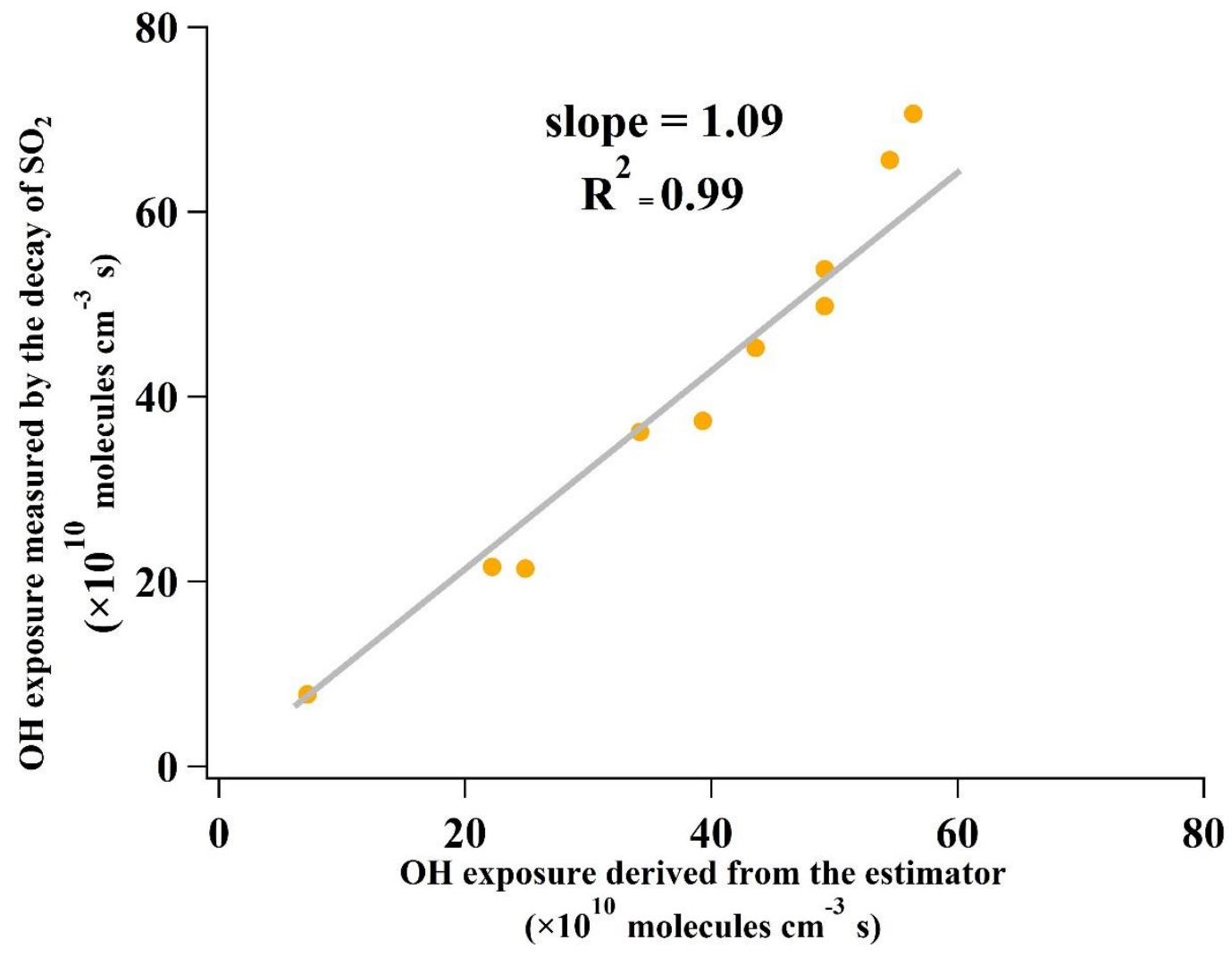

Figure S3. Comparison of measured and estimated $\mathrm{OH}$ exposures during off-line $\mathrm{OH}$ exposure calibration of the cooking experiment. 
(a) 5

4

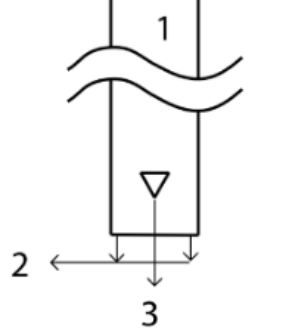

(d)
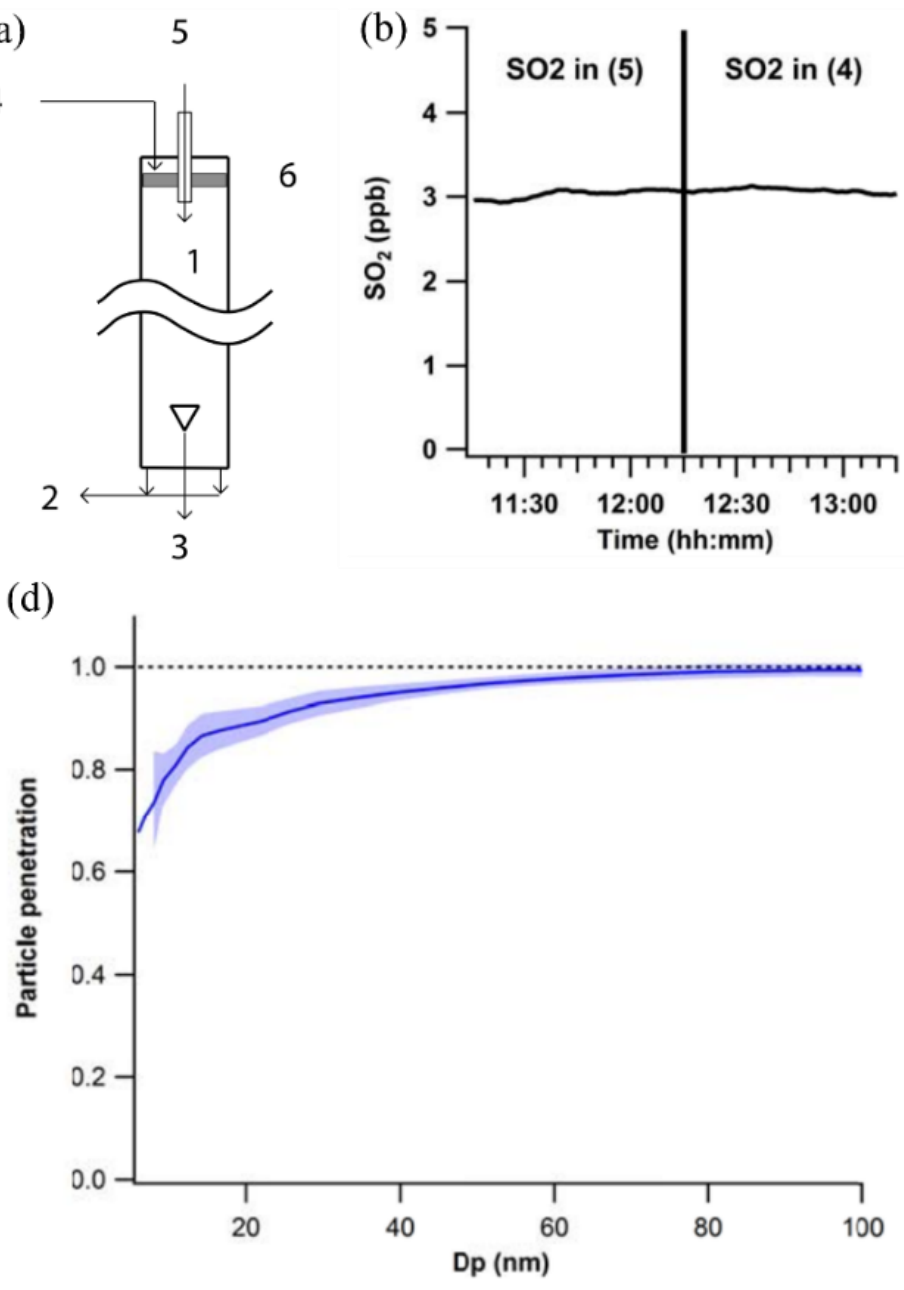

6

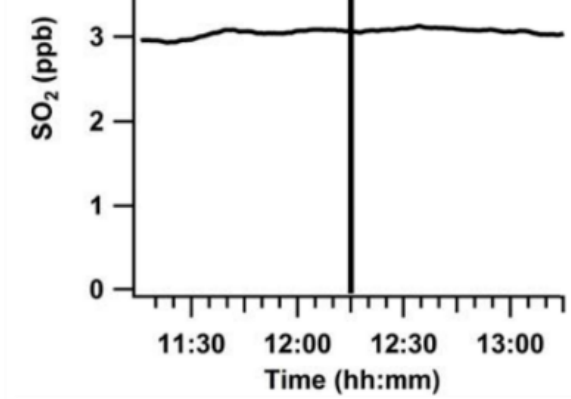

162

163

164

165

166

167

168

169

170

171 low signal-to-noise ratio (Watne et al., 2018).

Figure S4. Previous performance tests for Go: PAM: (a) The schematic diagram of the Go: PAM reactor. (1) Quartz glass flow reactor; (2) Exhaust flow; (3) Processed sample flow; (4) Humidified oxidant flow; (5) Sample flow; (6) Gas distributor plate (Watne et al., 2018). (b) $\mathrm{SO}_{2}$ added in turn in the "sample flow" (flow 5) and the "oxidant flow" (flow 4), and sampled from "processed sample flow" (Watne et al., 2018). (c) Modeled fractional fates of LVOCs loss as a function of the equivalent photochemical age in the Go: PAM (Li et al., 2019). (d) The particle penetration (Pp) as a function of the particle mobility diameter (Dp) in Go: PAM. The solid line and shaded area represent the average and one standard deviation of the five different mass loadings of the nebulized ammonium sulfate particles (39-258 $\mu \mathrm{g} / \mathrm{m} 3)$, respectively. The dashed black line represents $100 \%$ of particle penetration. The values for the first two size bins $(6.04$ and $6.98 \mathrm{~nm})$ were extrapolated due to the 


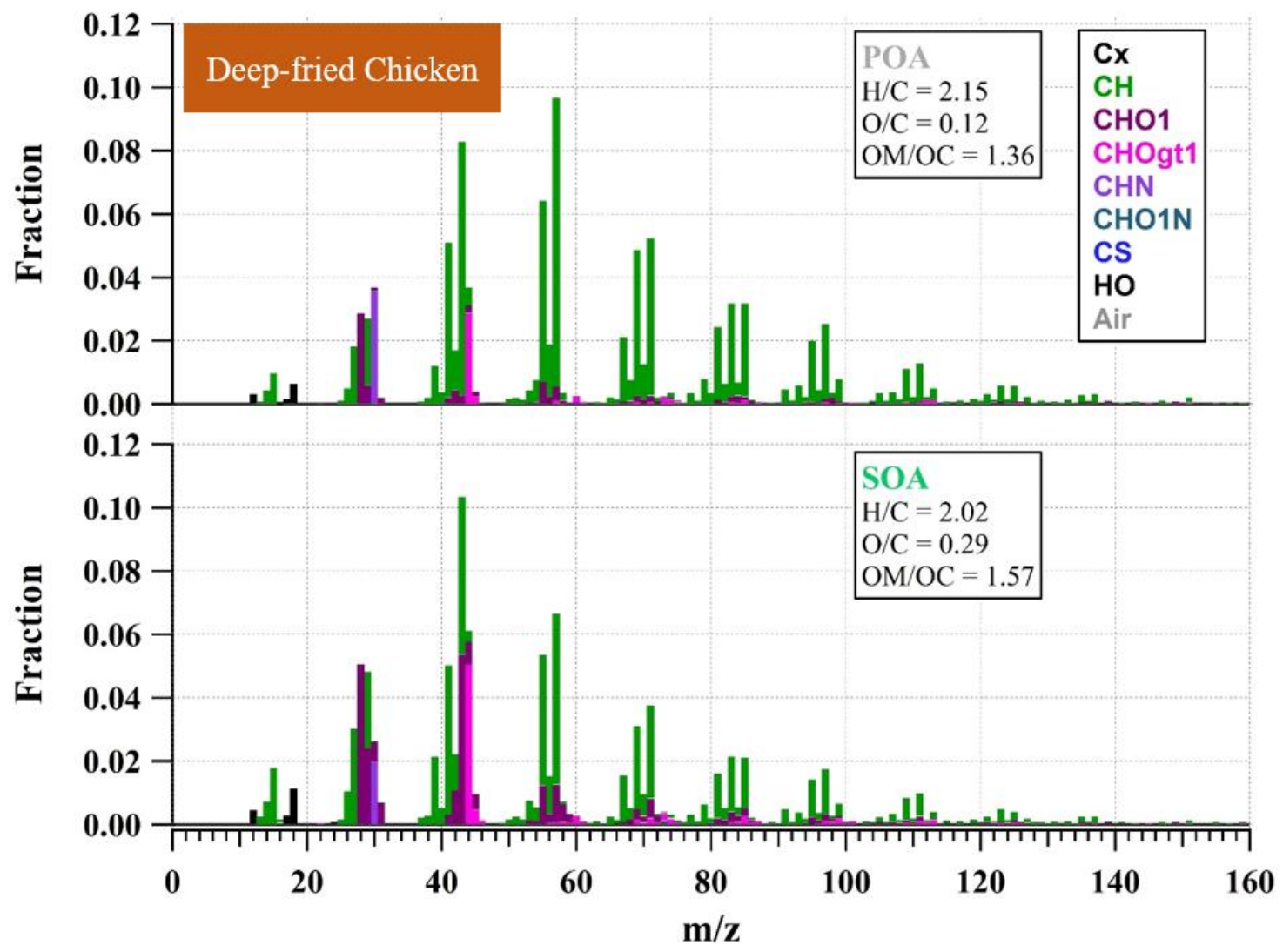

Figure S5. Mass spectra of PMF- resolved POA and SOA factors for deep-fried chicken groups.

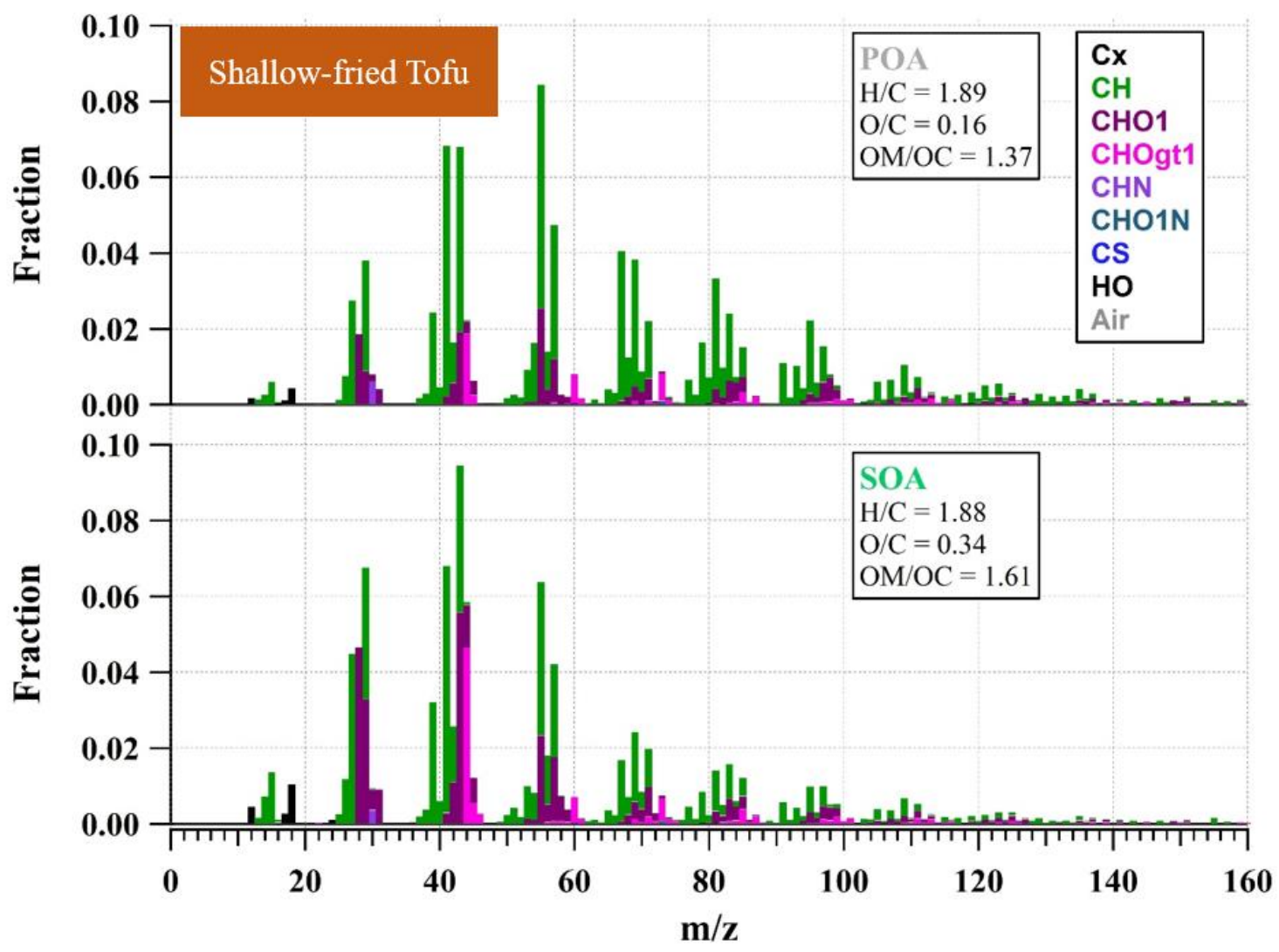

Figure S6. Mass spectra of PMF- resolved POA and SOA factors for shallow-fried tofu groups. 


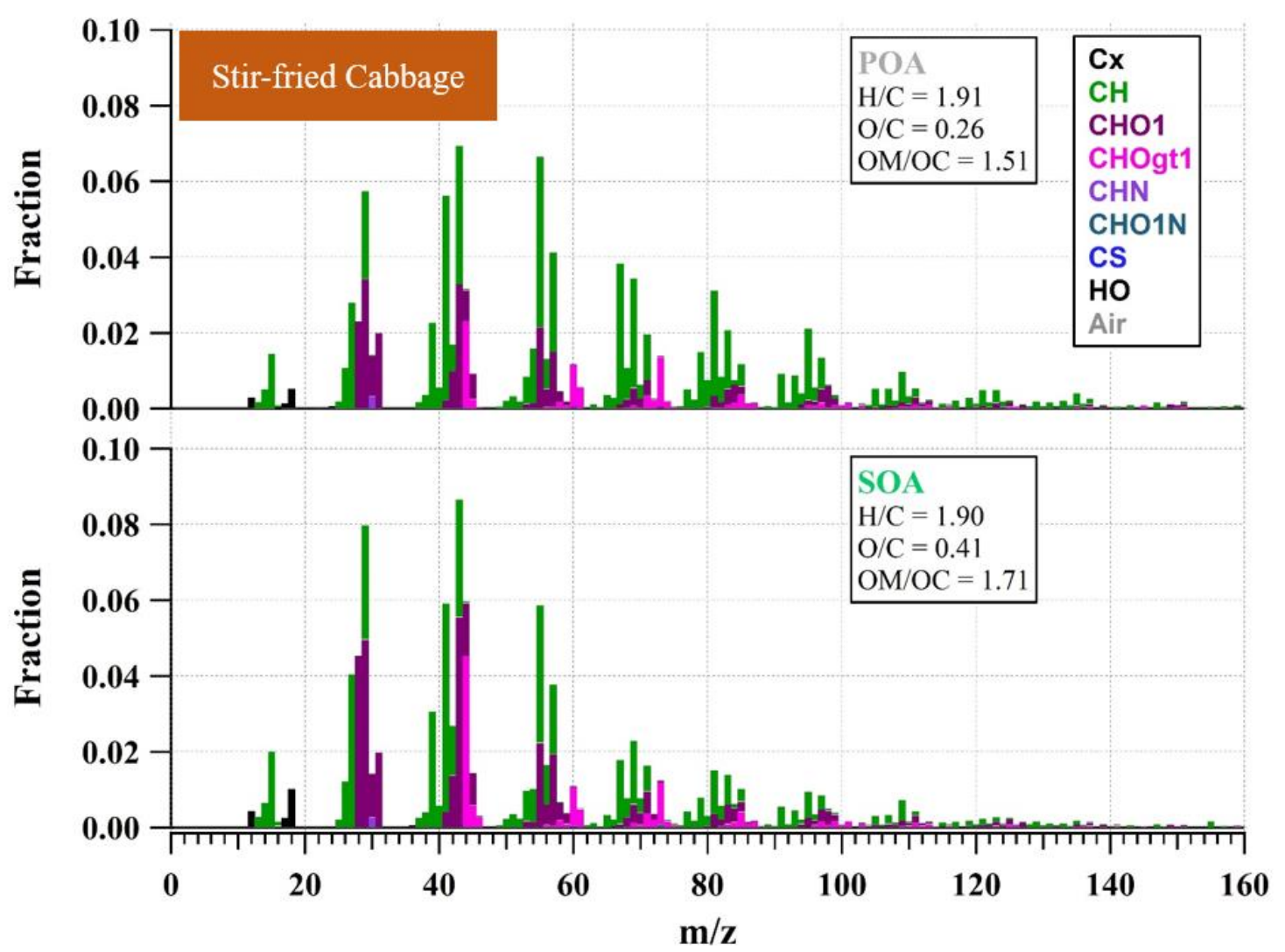

Figure S7. Mass spectra of PMF- resolved POA and SOA factors for stir-fried cabbage vegetable groups.

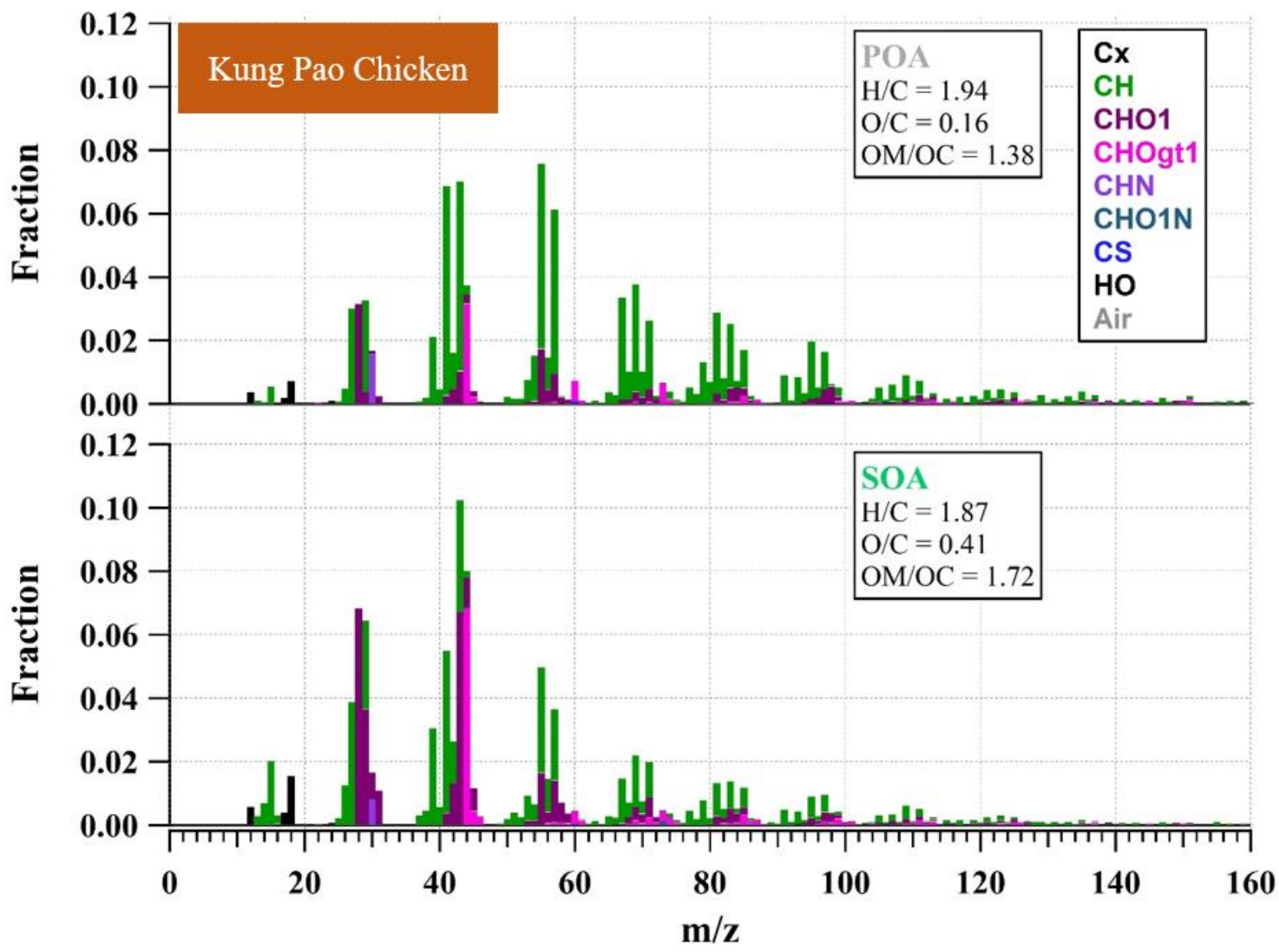

Figure S8. Mass spectra of PMF- resolved POA and SOA factors for Kung Pao chicken groups. 

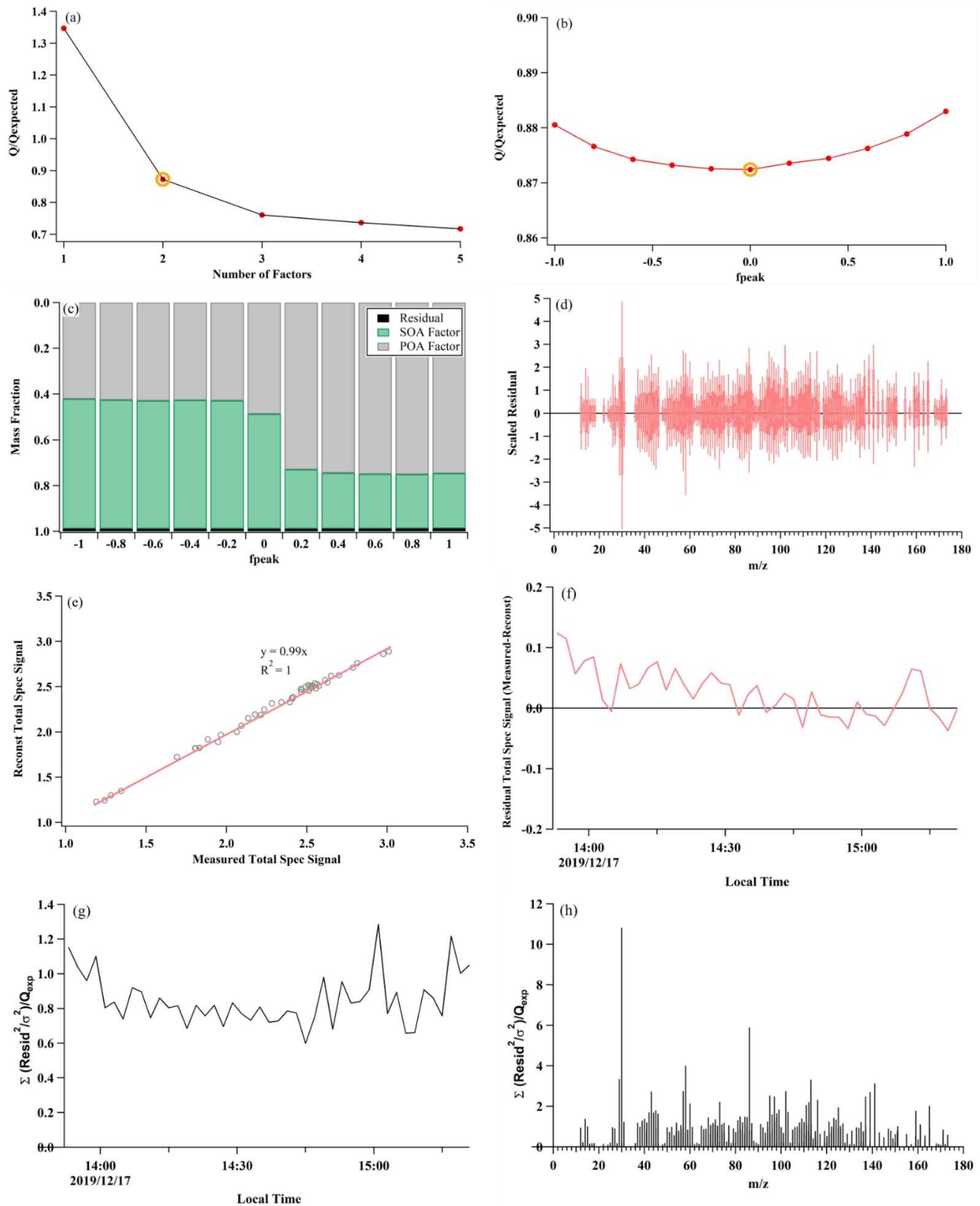

Figure S9. Diagnostic plots of the PMF analysis for deep-fried chicken groups. The following plots are shown (a) Q/Qexp vs the number of factors; (b) Q/Qexp vs. fpeak for the solution with optimal number of factors; (c) mass fraction of PMF factors vs. fpeak; (d) the distribution of scaled residuals for each $\mathrm{m} / \mathrm{z}$; (e) comparison of the reconstructed and measured total organic mass; (f) time series of the residual of PMF solutions; (g) time series of Q/Qexp; (h) the Q/Qexp vs. m/z. 

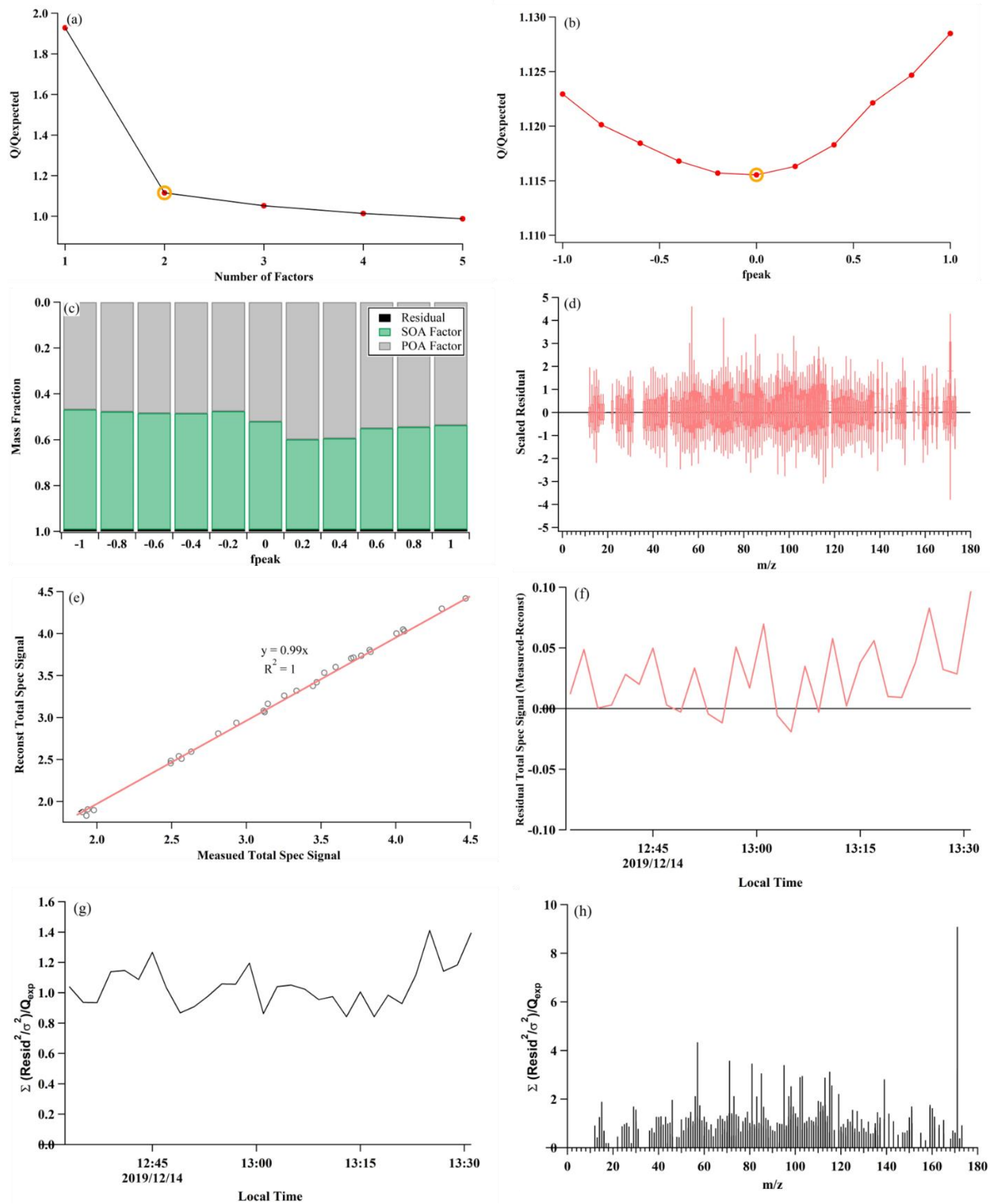

Figure S10. Diagnostic plots of the PMF analysis for shallow-fried tofu groups. The following plots are shown (a) Q/Qexp vs the number of factors; (b) Q/Qexp vs. fpeak for the solution with optimal number of factors; (c) mass fraction of PMF factors vs. fpeak; (d) the distribution of scaled residuals for each $\mathrm{m} / \mathrm{z}$; (e) comparison of the reconstructed and measured total organic mass; (f) time series of the residual of PMF solutions; (g) time series of Q/Qexp; (h) the Q/Qexp vs. m/z. 

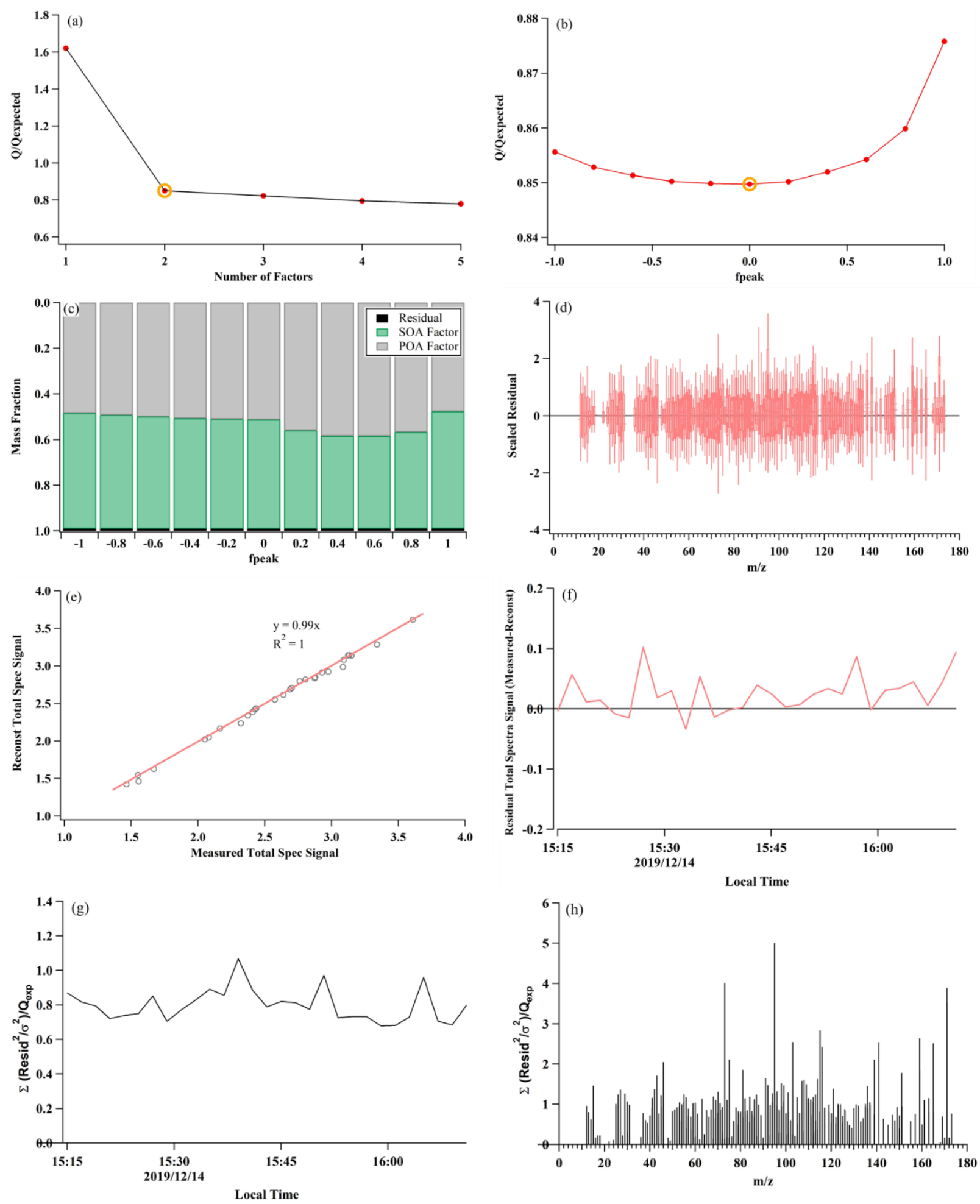

Figure S11. Diagnostic plots of the PMF analysis for stir-fried cabbage groups. The following plots are shown (a) Q/Qexp vs the number of factors; (b) Q/Qexp vs. fpeak for the solution with optimal number of factors; (c) mass fraction of PMF factors vs. fpeak; (d) the distribution of scaled residuals for each $\mathrm{m} / \mathrm{z}$; (e) comparison of the reconstructed and measured total organic mass; (f) time series of the residual of PMF solutions; (g) time series of Q/Qexp; (h) the Q/Qexp vs. m/z. 

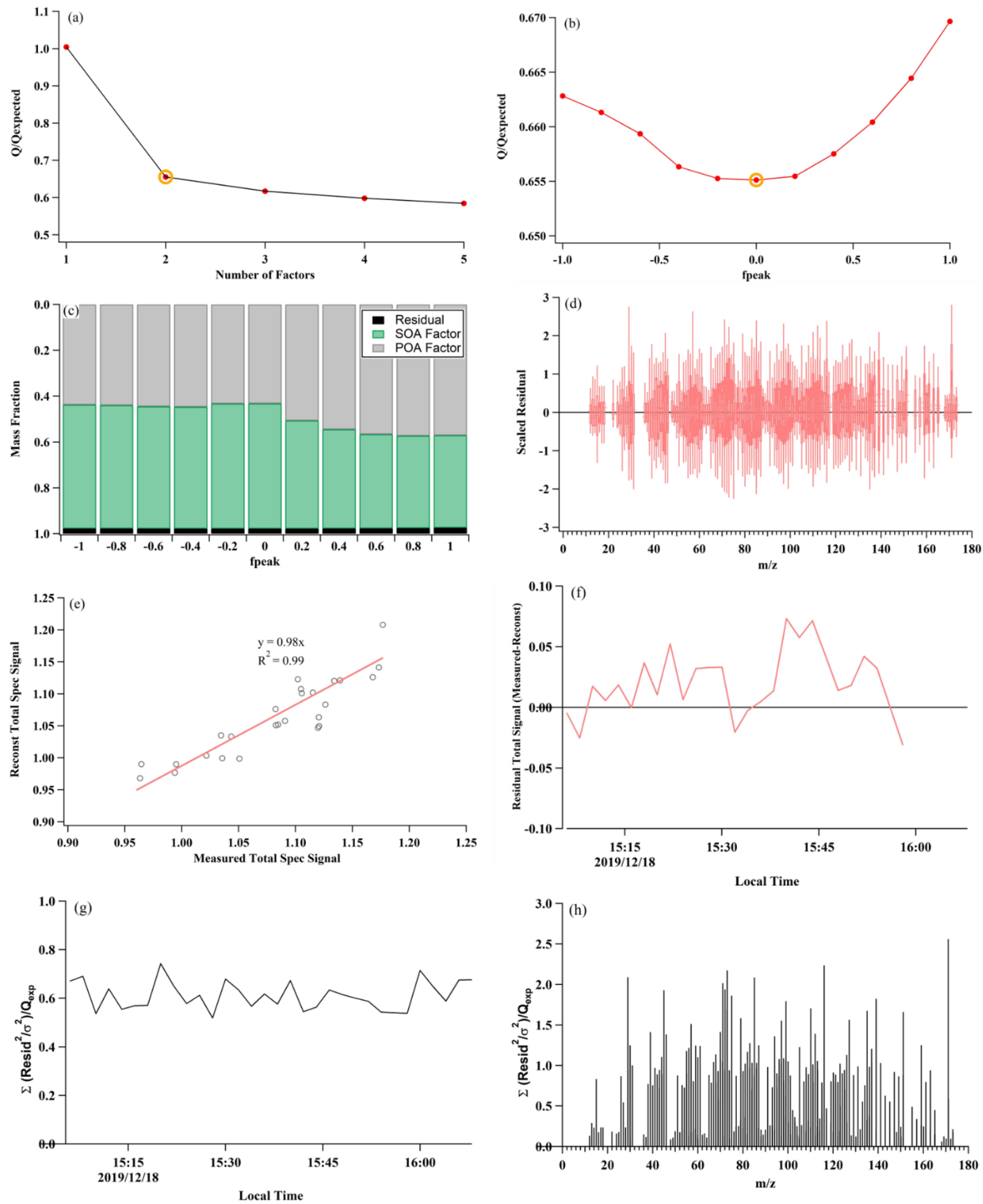

Figure S12. Diagnostic plots of the PMF analysis for Kung Pao chicken groups. The following plots are shown (a) Q/Qexp vs the number of factors; (b) Q/Qexp vs. fpeak for the solution with optimal number of factors; (c) mass fraction of PMF factors vs. fpeak; (d) the distribution of scaled residuals for each $\mathrm{m} / \mathrm{z}$; (e) comparison of the reconstructed and measured total organic mass; (f) time series of the residual of PMF solutions; (g) time series of Q/Qexp; (h) the Q/Qexp vs. m/z. 


\section{References:}

Li, J., Liu, Q., Li, Y., Liu, T., Huang, D., Zheng, J., Zhu, W., Hu, M., Wu, Y., Lou, S., Hallquist, Å. M., Hallquist, M., Chan, C. K., Canonaco, F., Prévôt, A. S. H., Fung, J. C. H., Lau, A. K. H., and Yu, J. Z.: Characterization of Aerosol Aging Potentials at Suburban Sites in Northern and Southern China Utilizing a Potential Aerosol Mass (Go:PAM) Reactor and an Aerosol Mass Spectrometer, Journal of Geophysical Research: Atmospheres, 124, 5629-5649, 10.1029/2018jd029904, 2019.

Li, J., Gao, W., Cao, L., Xiao, Y., Zhang, Y., Zhao, S., Liu, Z., Liu, Z., Tang, G., Ji, D., bo, H., Song, T., He, L., Hu, M., and Wang, Y.: Significant changes in autumn and winter aerosol composition and sources in Beijing from 2012 to 2018: effects of clean air actions, Environmental pollution, 115855, 10.1016/j.envpol.2020.115855, 2020a.

Li, J., Liu, Z., Gao, W., Tang, G., Hu, B., Ma, Z., and Wang, Y.: Insight into the formation and evolution of secondary organic aerosol in the megacity of Beijing, China, Atmospheric Environment, 220, 117070, 10.1016/j.atmosenv.2019.117070, $2020 \mathrm{~b}$.

Palm, B. B., Campuzano-Jost, P., Ortega, A. M., Day, D. A., Kaser, L., Jud, W., Karl, T., Hansel, A., Hunter, J. F., Cross, E. S., Kroll, J. H., Peng, Z., Brune, W. H., and Jimenez, J. L.: In situ secondary organic aerosol formation from ambient pine forest air using an oxidation flow reactor, Atmospheric Chemistry and Physics, 16, 2943-2970, 10.5194/acp-16-2943-2016, 2016.

Watne, A. K., Psichoudaki, M., Ljungstrom, E., Le Breton, M., Hallquist, M., Jerksjo, M., Fallgren, H., Jutterstrom, S., and Hallquist, A. M.: Fresh and Oxidized Emissions from In-Use Transit Buses Running on Diesel, Biodiesel, and CNG, Environmental science \& technology, 52, 7720-7728, 10.1021/acs.est.8b01394, 2018.

Wiedensohler, A., Birmili, W., Nowak, A., Sonntag, A., Weinhold, K., Merkel, M., Wehner, B., Tuch, T., Pfeifer, S., Fiebig, M., Fjäraa, A. M., Asmi, E., Sellegri, K., Depuy, R., Venzac, H., Villani, P., Laj, P., Aalto, P., Ogren, J. A., Swietlicki, E., Williams, P., Roldin, P., Quincey, P., Hüglin, C., Fierz-Schmidhauser, R., Gysel, M., Weingartner, E., Riccobono, F., Santos, S., Grüning, C., Faloon, K., Beddows, D., Harrison, R., Monahan, C., Jennings, S. G., O'Dowd, C. D., Marinoni, A., Horn, H. G., Keck, L., Jiang, J., Scheckman, J., McMurry, P. H., Deng, Z., Zhao, C. S., Moerman, M., Henzing, B., de Leeuw, G., Löschau, G., and Bastian, S.: Mobility particle size spectrometers: harmonization of technical standards and data structure to facilitate high quality long-term observations of atmospheric particle number size distributions, Atmospheric Measurement Techniques, 5, 657-685, 10.5194/amt-5$657-2012,2012$. 